\title{
Analisis Manajemen Klasifikasi Masyarakat Muslim Pancasila Berasaskan Epistimologi Pendidikan
}

\author{
Ihwan Fauzi ${ }^{1 *}$, Subiyantoro ${ }^{1}$
}

${ }^{1}$ UIN Sunan Kalijaga Yogyakarta, Indonesia

\author{
A R T I C L E I N F O \\ Article history: \\ Received 24 Agustus 2020 \\ Accepted 12 Juni 2021 \\ Available online 30 Juni \\ 2021 \\ Kata Kunci: \\ Epistimologi Pendidikan; \\ Kesadaran Masyarakat; \\ Muslim; Pancasila \\ Keywords: \\ Epistemology of Education; \\ Awareness; Muslim; \\ Pancasila
}

\begin{abstract}
A B S T R A K
Penelitian ini bertujuan untuk mengetahui epistimologi pendidikan berdasarkan klasifikasi masyarakat muslim yang berlandaskan pancasila. Sesuai dengan permasalahan dalam penelitian ini maka peneliti menggunakan library research (penelitian pustaka) dalam analisisnya. Library research ialah suatu penelitian yang menjadikan bahan pustaka sebagai sumber data utama (penting), sehingga lebih kepada dokumentasy research (penelitian dokumentasi). Analisis data yang digunakan adalah content analysis (Analisis isi) adalah penelitian yang bersifat pembahasan mendalam terhadap konten suatu informasi tertulis atau tercetak (printed) dalam media massa. Metode komparatif yaitu mencari relevansirelevansi antara bermacam data dari beberapa kalimat, opini yang diperoleh menggunakan pendekatan kualitatif, setelah itu dibandingkan antara data-data tersebut untuk diambil kesimpulan-kesimpulan. Hasil penelitian menyebutkan bahwa Pancasila adalah rumah bersama, tempat semua kelompok agama (termasuk islam) dapat mengisi dan memperkaya
\end{abstract} nilai-nilai luhur kemanusiaan yang menjadi inti Pancasila. Landasan berpikir masyarakat muslim yang berlandaskan pancasila ialah rasional, empirik dan intuitif. Menjadi masyarakat yang hanafiyyah, menjadikan nalar abduktif sebagai jalan untuk menjadikan bangsa Indonesia yang memiliki rasa keyakinan, rasa kemanusiaan, rasa persatuan, rasa musyawarah, dan rasa keadilan yang diwujudkan dalam kehidupan sehari-hari.

\section{A B S T R A C T}

This study aims to determine the epistemology of education based on the classification of the Muslim community based on Pancasila. Following the problems in this study, the researcher used library research in the analysis. Library research made library materials the primary (essential) data source so that it was more of documentary research. The data analysis used was content analysis, research that had the character of in-depth discussion of the content of written or printed information in the mass media. The comparative method looked for the relevance between various data from several sentences, the opinion obtained using a qualitative approach, after which it was compared between the data to conclude. The research result states that Pancasila is an ordinary house, where all religious groups (including Islam) can fill and enrich the noble values of humanity, which are the core of Pancasila. The thinking basis of Muslim society, based on Pancasila, is rational, empirical, and intuitive. Becoming a hanafiyyah society makes abductive reasoning a way to make the Indonesian nation have a sense of belief, humanity, sense of unity, sense of deliberation, and a sense of justice manifested in everyday life. 



\section{Pendahuluan}

Kondisi bangsa Indonesia sekarang ini, dihiasi dan disinyalir oleh makin renggangnya kohesi sosial serta munculnya wacana selain Pancasila sebagai Ideologi negara. Hal tersebut menjadi pendorong utama banyak pihak untuk membicarakan kembali Pancasila. Di salah satu hal ini patut disyukuri karena menandakan adanya kesadaran kelangsungan hidup bersama kita sebagai suatu bangsa. Secara tegas dapat dikatakan bahwa pada dekade terakhir ini, telah terjadi krisis rasa kebersamaan, kesamaan, dan kekeluargaan bermasyarakat, berbangsa dan bernegara. Fakta paling akurat misalnya dalam dunia politik, hukum, dan sosial kebudayaan.

Politik di negeri ini menampilkan politik demokrasi liberalistik, kapitalisistik, anarkhis, intimidasi yang secara reflektif politik semacam itu adalah politik yang dilandasi oleh paham materialistik, individualistik, egoistik, mementingkan kelompok dan golongan serta membumi hanguskan pihak lain yang menjadi mandul, karena kentalnya paham materialistik, sehingga tidak jarang hukum diperjualbelikan, akibatnya keadilan menjadi mati dari seluruh jagad negeri ini. Hukum tidak lagi menjadi alat untuk mempertahankan serta melindungi rakyat Indonesia dan negara, tetapi sudah menjadi lumbung materi dan barang mewah yang itu sesungguhnya menyengsarakan umat manusia. Kehidupan sosialitas menjadi berantakan karena diterjang oleh arus dan badai individualitas dan materialitas (Yusuf, 2013).

Sesuai dengan yang dikatakan Mohandas K. Gandhi bahwa bagian dari 7 (tujuh) dosa sosial ialah pendidikan tanpa karakter. Hal itu tentu saja bukan tanpa alasan, sebab kejatuhan sebuah bangsa bukan semata-mata ditimbulkan oleh sumber daya alamnya yang gersang atau ketiadaan alat produksi untuk menopang kemajuan, melainkan karena kemerosotan karakter dan moral.

Krisis inilah yang sejatinya tengah, mendera bangsa kita saat ini. Maraknya pertikaian, kehancuran tata nilai, kebobrokan moral, serta sburnya praktik korupsi, misalnya, adalah serentetan bukti yang bisa diajukan. Krisis multidimensi tersebut jelas bukanlah persoalan sepele yang bisa dirampungkan secara timbal sulam. Menyadari hal itu, pemerintah melalui kementerian Pendidikan dan Kebudayaan meresponnya dengan menggalakkan pendidikan karakter secara menyeluruh sesuai dengan tujuan pendidikan nasional yang tertera pada UU No. 20 tahun 2003. Yang sasarannya meliputi seluruh masyarakat Indonesia (termasuk muslim) yang berasaskan pada Pancasila. Pendidikan karakter dipandang sebagai solusi terbaik untuk mengatasi persoalan tersebut. Oleh sebab itu, kurikulum pendidikan disusun dan diadakan pelatihan serta diberikan berbagai muatan belajar untuk membentuk masyarakat berkarakter dan siap mengabdi untuk bangsa Indonesia. dan kemudian diimplementasikan berdasarkan epistimologi pendidikan yang selaras denga jiwa masyarakat Indonesia (termasuk muslim). Akhir-akhir ini dalam kehidupan kemasyarakatan di negara kita NKRI ,di kalangan birokrat, kaum pendidik, para orang tua dan generasi muda Indonesia mulai resah, kawatir/kecewa adanya krisi keteladanan. Pancasila sebagai ideologi berbangsa dan bernegara mestinya nilainilai yang hidup pada masyarakat Indonesia sehari-hari, namun dirasakan semakin tidak jelas dan jauh dari harapan (Adi, 2016).

Sebab itu dapat lah kita mengerti kenapa pada umat-umat sebelum umat Nabi Muhammad S.A.W pada waktu tertentu Allah mengutus nabi untuk meluruskan kembali rel yang telah menyimpang atau disimpangkan oleh manusia. Tapi, setelah semua agama samawi Allah ini disempurnakan dengan nama islam, maka tidak diturunkan lagi nabi atau rosul, karena nabi Muhammad sebagai utusan terakhir dan telah dinilai oleh Allah dapat mengemban misi yang ditugaskan Allah kepadanya. Maka islam memandang salah satu alat dan upaya untuk melestarikan moral ini adalah melalui pendidikan. Masyarakat islam yang berlandaskan pancasila harus sadar bahwa tujuan pendidikan nasional adalah berdasar dengan landasan yang dituangkan dalam Alquran.

\section{Metode}

Metode penelitian yang digunakan dalam penyusunan penelitian ini adalah studi kepustakaan (Library Research) yaitu pendalaman terhadap berbagai literatur bacaan, mulai dari buku-buku. Artikel-artikel ilmiah, dan berbagai referensi untuk menemukan klasifikasi 
masyarakat muslim pancasila dan epistimologi pendidikannya. menggunakan library research (penelitian pustaka) dalam analisisnya. Analisis data yang digunakan adalah content analysis (Analisis isi) adalah penelitian yang bersifat pembahasan mendalam terhadap konten suatu informasi tertulis atau tercetak (printed) dalam media massa. Metode komparatif yaitu mencari relevansi-relevansi antara bermacam data dari beberapa kalimat, opini yang diperoleh menggunakan pendekatan kualitatif yang dikhususkan terutama bagi mahasiswa dan masyarakat dengan menggunakan purposif random sampling sesuai tujuan penelitian. setelah itu dibandingkan antara data-data tersebut untuk diambil kesimpulan-kesimpulan.

\section{Hasil dan pembahasan}

\section{Epistimologi Pendidikan}

Epistimologi ialah salah satu bagian filsafat yang menjelaskan sumber (dari mana diperoleh), proses (bagaimana proses), syarat, batas (sampai mana batas kajian), validitas (keabsahan) dan hakikat pengetahuan dalam hal ini menganai pendidikan. Alat-alat memperoleh pengetahuan filsafat pendidikan, yakni indera, akal, dan hati nurani. Yang menalaah segala hal melalui pemikiran rasional, empiris dan intuitif. Epistemologi dalam Perspektif Bermacam Aliran Filsafat Dunia.

\section{1) Epistemologi idealisme}

Epistemologi idealisme ini memastikan kurikulum yang dimaslahatkan dalam pendidikan lebih bertitik pada isi secara objektif menyediakan berbagai pengalaman belajar (lembaga pendidikan) sebanyak-banyaknya, pada subjek didikannya untuk mampu menggerakan hati dan jiwanya pada berbagai realitas yang akan mengubah cara berfikir dan pengamatannya terhadap keseluruhan realitas (kenyataan) pengalamannya. Pribadi Idealisme merupakan pribadi yang peka (mudah merasa) terhadap realitas di lingkungan sekitar dirinya, sehingga tidak Satu pun peristiwa yang dilihat dan didengarnya serta dirasakannya luput dari pikirannya. Sedemikian rupa hingga menimbulkan kepribadian yang cermat, cerdas dan tangkas dalam mencerna keseluruhan realitas (kenyataan) yang terbangun dari ruang idenya (Qomar, 2005).

\section{2) Epistemologi Realisme}

Epistemologi pendidikan dalam pemahaman realisme adalah proses ilmiah yang dialamtkan pada berbagai hal-hal yang beragam mengenai permasalahan pendidikan seperti hal berkaitan realitas (kenyataan) peserta didik (siswa, mahasiswa dsb), pendidik (guru, dosen, dsb), dan isi inti pendidikan, serta strategi yang baik dan lain sebagainya yang bisa dipakai oleh seseorang dan atau sekelompok orang menjadi (sebagai) fondasi utama dalam melaksanakan kegiatan pendidikan. Realisme mengajarkan bahwa menanamkan dan tumbuhkan pengetahuan tertentu kepada anak yang sedang tahap pertumbuhan dan perkembangan merupakan tugas paling urgen di sekolah. Oleh karena itu, inisiatif dan kreatifitas dalam implementasinya terletak pada guru sebagai pengalihan warisan (kebaikan) bukan pada peserta didik. Guru yang selalu membimbing ke arah mana saja subjek didik mau diarahkan dan apa saja subjek materi (pembahasan) yang mesti mereka pelajari di dalam ruang kelas. Epistemologi yang sudah diterangkan diatas meniscayakan bahwa setiap proses pembelajaran (PBM) mesti melalui pendekatan induktif, bukan deduktif. Pendekatan ini baginya adalah metode yang sesuai untuk menanamkan pengetahuan (keterampilan) dan nilai (values) dari subjek didik. Baginya, hal ini senada dengan watak (karakter) manusia dalam mendapatkan pengetahuan yang memang bersentuhan dengan berbagai sendi-sendi dunia yang secara nyata (realistik) saling terhubung dangan satu sama lain. Realisme percaya, bahwa manusia mengetahui dunia dari bagianbagiannya yang bersifat materi dan teridentifikasi dalam kriteria yang terukur (ternilai) dan nyata (Suparno, 2001). 


\section{3) Epistemologi Pragmatisme}

Menurut penganut pragmatisme bukanlah dikatakan pengetahuan, jika tidak memberikan perubahan bagi kehidupan bangsa. Jadi nilai pengetahuan dapat dilihat dari kadar instrumentnya yang akan membawa beberapa akibat, baik yang, sesudah atau yang akan dihasilkan oleh ide pikiran (mind) dalam dunia pengalaman yang nyata. Menurut penganutnya, guru wajib mengonstruksi keadaan belajar dengan memposisikan problem (masalah) tertentu yang penyelesaiannya akan membawa peserta pada pemahaman yang lebih baik (membawa kebaikan) akan lingkungan sosial dan fisik sekitar mereka. Akibatnya, menggantikan struktur konservatif tentang subjek materi baik guru maupun kelas harus mermproyeksikan apakah peengalaman itu memberikan berbagai manfaat dalam penyelesaian problem tertentu yang sedang mereka permasalahkan, seperti persoalan-persoalan seksual kurun waktu ini ataupun permasalahan kehidupan masyarakat Indonesia hari ini. Sehingga menjadikan ini lebih memiliki nilai bagi subjek didik (peserta didik) dan akan semakin mudah dipmengerti ketika mereka dapat memanfaatkannya sebagai alat yang dapat memberi kepuasan terhadap kebutuhan dan kepentingan peserta didik dalam menghadapi realitas sosial. Menurut penganut pragmatis, seorang anak selalu belajar secara alamiah mengenai suatu hal sebagai pemahaman bahwa memang mereka adalah makhluk yang secara alami selalu ingin mengetahui tentang sesuatu. Ia akan senantiasa mempelajari berbagai macam yang mereka rasakan dan yang mereka pikirkan. Mengajar peserta didik dari materi telah jelas baginya merupakan suatu kebutuhan nyata (real) bagi subjek didik dalam melaksanakan kegiatan belajar (PBM). Tugas urgen guru adalah membantu dan mengararahkan subjek didiknya agar mampu memahami dan untuk merangsang jiwa ingin tahunya yang acap kali tumbuh dan berkembang. Penganut pragmatisme juga memiliki keyakinan bahwa subjek didik harus mempelajari keingintahuan, serta guru mesti merangsang rasa ingin tahu itu tampil di dalam proses inquiry.

\section{4) Epistemologi Eksistensialisme}

Epistemologi Eksistensialisme adalah suatu eksistensi yang menjadi pilihan sesorang dalam kebebasan. Bereksistensi bermakna bereksistensi dalam suatu tindakan yang harus dipahami oleh masing-masing orang bagi diri sendiri. Pilihan bukanlah masalah teoritikal melainkan soal komitmen (konsisten) total seluruh individu. Berangkat dari kebebasan bukan bebas sebebasnya sebagai corak bereksistensi, dengan hal demikian agar tidak menempatkan personal ke dalam realitas yang abstrak (tidak nyata) tetapi individu (diri) dilihat menjadi satu individu yang sungguh ada dan konkrit. Oleh karena itu, dalam metode pengambilan suatu keputusan, hanya yang konkrit (nyata) yang dapat memutuskan atas diri sendiri bukan pada orang lain. Individu lain tidak mempunyai hak untuk memutuskan pilihan atas apa yang akan dilakukan. Barang siapa yang tidak memiliki keberanian mengambil keputusan, maka ia tidak bereksistensi dalam arti yang sesunngguhnya. Hanya orang yang memiliki keberanian yang memtuskan untuk dapat bereksistensi dengan memutuskan atas pilihannya sendiri, maka dia akan menentukan kemana tujuan dan arah mata angin hidupnya.

\section{Dasar Ontologi Kesadaran Masyarakat Muslim}

Pemahaman Diniyyah secara ontologis bahwa masyarakat muslim yang berkesadaran jahiliyyah seperti ini cenderung memahami realitas/yang ada sebagaimana yang tampak di depannya (dunia indrawi) dan yang ada di balik yang konkrit (dunia rasional). Artinya realitas mereka pahami sebagaimana kejadiannya; dengan cara instan, jangka pendek dan sederhana. Di samping itu meskipun realitas dipahami sebagaimana adanya seperti itu, namun pada saat yang sama realitas dipandang sebagai sesuatu yang lain secara kontradiktif (ada rasional/rekayasa, yang justru sebenarnya tidak rasional). Ini dikarenakan bukan oleh ketidaktahuan mereka, melainkan justru karena kesengajaan (sebenarnya tahu tapi kemudian sengaja pura-pura tidak tahu/membodoh).

Jadi subjek mendominasi objek dalam rangka rekayasa atau memutarbalikkan fakta. Secara ontologis, mestinya mereka termasuk berpaham dualisme, akan tetapi dalam prakteknya mereka memandang realitas dengan sebelah mata; yang empirik dan rasional/dunia dan 
akhirat, ada, akan tetapi rasional dan atau akhirat dibekukan (membodoh) demi mengutamakan dunia/materi/empirik.

Pemahaman ontologi diniyyah, Apabila dirujukkan kepada sikap keberagamaan mereka yang berkesadaran/paradigma diniyyah yang mengakui adanya dunia dan akhirat serta cenderung membedakan keduanya dalam hirarki akhirat lebih utama dibanding dunia. Artinya realitas dalam keadaan material/konkrit/dunia (lebih rendah) dan spiritual/ruh/akhirat (lebih utama/tinggi). Konsekuensinya orang akan lebih menitikkankan perhatiannya pada yang utama tersebut, walaupun dunia tetap tidak ditinggalkan sama sekali (Asmaroini, 2017).

Pandangan dunia/ontologis seperti di atas pastinya dipandu oleh dalil/nas yang diyakini sebagai sumber kebenaran (al-Qur'an)wahyu yang berasal dari Allah, dan juga hadis/sunnah Rasul yang merupakan penafsiran (penjelasan) dari al-Qur'an tersebut.

Selanjutnya oleh sebab itu pengakuan bahwa secara ontologis manusia adalah sebagai wakilnya di bumi ini dan segala kiprahnya harus senantiasa sesuai dengan kehendaknya maka seluruh pengetahuannya merupakan limpahan yang telah ditetapkan oleh Nya qudroh ilahiyah sebagaimana disebut pada surah al-Baqarah ayat 114-115 di dalam hal ini pengetahuan nabi Adam tentang segala sesuatu adalah karena pemberiannya demikian pula keterbatasan pengetahuan Malaikat juga dipahami merupakan kebijaksanaan Allah (Usman, 2013).

Di sini tampak bahwa sumber pengetahuan manusia adalah objek, baik empirik maupun spiritual dan jika terkait dengan metode/proses perolehan pengetahuan terhadap yang empirik adalah dengan indrawi. Adapun rasio atau akal hanya dapat digunakan untuk menjelaskan nama, posisi, jumlah, fungsi serta hubungan dari masing-masing sesuatu yang ada di dunia ini yang empirik. Sedangkan yang spiritual Allah malaikat jin dan akhirat proses perolehan dengan intuisi berdasar informasi wahyu Allah lewat rasulnya yang diterimanya. Validitas dari masingmasing pengetahuan tersebut didasarkan pada pengakuan terhadap kualitas objek serta sarana perolehan pengetahuan empirik indrawi dan bisa akal atau rasional serta spiritual-intuisi.

Pemikiran ontologis Ilmiyyah, sikap dan perilaku ilmiyyah tercermin dalam suaru pandangan yang menyatakan bahwa realitas merupakan kenyataan yang sangat empirik/konkrit. Artinya ia merupakan sesuatu yang nyata/riil, bukan sekedar ungkapan konseptual yang jauh dari realitas. Kenyataan seperti itu jelas bersifat kuantitatif, sehingga setiap realitas dilihat sebagaimana halnya. Ia dalam kondisi yang beragam/plural, berbeda satu dengan yang lain serta selalu berubah/mengalami perubahan yang terus-menerus. Ia merupakan hal yang dinamis (selalu berubah) atau tidak stagnan.

Dalam dasar ontologi hanifiyyah, baik secara empiris, rasional, dan intuitif, itu semua dinyatakan ada atau sebagai realitas yang sungguh-sungguh nyata, dan manusia bisa menjangkaunya dengan sarana yang dimilikinya; indrawi, rasio, serta intuisi (Usman, 2013). Di sini tampak bahwa kesadaran/paradigma hanifiyyah yang selalu mengaitkan urusan dunia dengan ketuhanan dalam rangka pengabdiannya. Karena ia sadar dan mengakui bahwa realitas dunia ini keberadaannya tidak terlepas dari realitas yang-Ilahi; asal-usul dan keberlangsungannya dari awal hingga akhir. Itulah kesadaran/paradigma hanifiyyah yang secara ontologis mampu memposisikan sekaligus menghubungkan satu sama lain dari realitas yang ada. Allah sebagai realitas tunggal (tauhid) yang harus dipatuhi kebenarannya mewujud dalam etiap perilaku hukum, politik, dan agama). Realitas apapun dicerna melalui perpaduan empirisrasional-intuitifnya.

\section{Hakekat Masyarakat Muslim}

Manusia tidak dapat hidup sendirian. Karena dia adalah makhluk sosial yang selalu tergantung kepada orang lain. Bayi yang lahir tidak akan mampu hidup tanpa bantuan orang lain. Di samping manusia bergantung kepada manusia lain, juga karakteristik manusia itu ialah berkemampuan menyesuaikan diri (adaptability) dengan kondisi lingkungan yang dia hadapi. Kemampuan menyesuaikan diri itu dapat dilakukan manusia karena kemampuan berpikir (kognitif-akal), merasa karsa (afektif-nafs), kemampuan meyakini (qalb), dan melakukan (psikomotorik-al-jasad). Untuk itu manusia disebut makhluk sosial (Siregar, 2018).

Menurut Plato, ia tidak membedakan antara negara dan bangsa (masyarakat). Negara tersusun dari berbagai individu dan tidak disebutkan kesatuan yang lebih besar. Negara sama 
masyarakat, menurut Aristoteles memiliki ketidaksamaan antara negara dan (bangsa) masyarakat. Negara adalah sekumpulan dari berbagai unit kemasyarakatan. Masyarakat diposisikan atas keluarga-keluarga, sedangkan Comte memperluas analisis-analisis masyarakat, dengan menganut suatu paradigma tentang masyarakat sebagai lebih dari suaru agrigat (gerombolan) individu-individu. Masyarakat muslim adalah masyarakat pemeluk agama islam yang menjunjung (derajat) tinggi Alquran dan sunnah sebagai asas hokum (Adi, 2016).

Alquran membahas tentang masyarakat (ummah) dalam berbagai istilah, diantaranya istilah al-nas, bani adam, ummah, qabilah, qaum, thaifah atau jama'ah. Namun dalam beberapa istilah yang dipakai Alquran menyebut istilah ummah (masyarakat). Alquran menyebut kata ummah (masyarakat) sebanyak 51 kali. Manurut Jhon Penrince bahwa kata ummata berarti penduduk, bangsa, ras, kelompok, ketentuan, istilah tertentu, waktu dan agama tertentu. Muhammad Ismail Ibrahim mengartikannya dengan "kelompok manusia, muallim, seseorang yang baik, agama, dan waktu". Dari pengertian tersebut dapat dijelaskan bahwa ummah (masyarakat) adalah kumpulan manusia (orang-orang) yang saling berinteraksi (berkominkasi) bersama yang diikat oleh sesuatu (keyakinan atau agama, warisan budaya (adat), lingkungan keluarga, sosial, politik, tanah air, perasaan, cita-cita dan lain-lain) dalam rangka mencapai tujuan (cita-cita) hidup.

Menciptakan dan memberdayakan (memberi manfaat) masyarakat yang sesuai dengan tujuan-tujuan menciptakan manusia di bumi adalah tujuan dari pendidikan. instansi pendidikan sebagai kunci dalam mencapai tujuan sosial yang diharapkan. Pemerintah bersama anggota masyarakat dan orang tua telah memberi ruang (penyedia) anggaran pendidikan yang diperlukan untuk kemajuan masyarakat dan bangsa, untuk menanamkan nilai-nilai luhur yang berasal dari budaya dan dan nilai-nilai luhir yang berasal dari agama.

Pendidikan dapat diharapkan untuk mengembangkan wawasan dan keyakinan peserta didik terhadap agama yang dianutnya, idologi, ekonomi, sosial, budaya dan pertahanan pada individu, keluarga, masyarakat dan negara (Country) untuk menggapai masyarakat madani yang dijiwai nilai-nilai luhur (masa lalu) agama dan budaya (pancasila). Berbicara tentang fungsi pendidikan dalam masyarakat menurut Bloom adalah (1) transmisi dalam budaya, (2) meningkatkan integrasi sosial, (3) mengadakan pemilihan dan alokasi sumber daya melalui pendidikan, (4) mengembangkan kepribadian. Meta Spencer dan Alec Inkeles memberi pendapat bahwa manfaat pendidikan dalam lingkungan masyarakat itu sebagai berikut, (1) mengalihkan nilai budaya, (2) nilai pengajaran, (3) peningkatan perpindahan sosial, (4) fungsi pembedaan penduduk, (5) latihan jabatan, (6) mengingkatkan dan memantapkan hubunganhubungan sosial, (7) membentuk semangat kebangsaan.

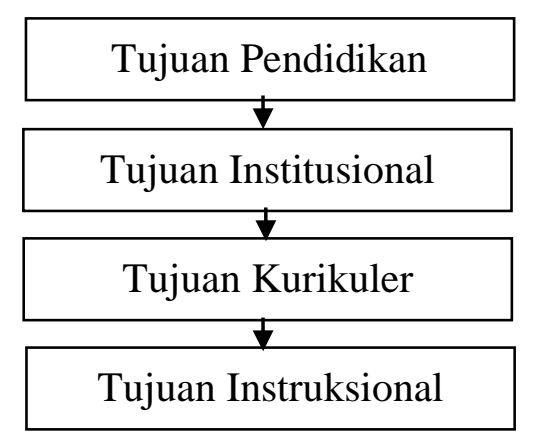

\section{Gambar 1. Hirarki Tujuan Pendidikan}

Undang-undang No.20 tahun 2003 tentang sistem pendidikan nasional pada pasal 3 menyebutkan bahwa; Pendidikan nasional berfungsi mengembangkan kemampuan dan membentuk karakter serta peradaban bangsa yang bermartabat dalam rangka mencerdaskan kehidupan bangsa (Wahid, 2013). Tujuan pendidikan di Indonesia tertuang pada UU RI No.20 tahun 2003 tentang sistem pendidikan nasional beserta aturan-aturan pemerintah yang berhubungan dengan pendidikan. 


\section{Pancasila (Kedudukan Dan Fungsi)}

Pancasila berasal dari kristalisasi nilai-nilai yang sudah ada di indonesia sejak jaman dahulu yang tercermin di dalam adat-istiadat, agama dan kepercayaan serta kebudayaan. Nilainilai itu diambil lima intinya yang kemudian dirumuskan menjadi lima hal yang merupakan unsur-unsur pencasila. Pancasila bagi masyarakat dan negara Indonesia berkedudukan dan berfungsi sebagai berikut.

\section{Pancasila sebagai pandangan hidup bangsa indonesia}

Pandangan hidup bangsa tercermin di dalam pancasila yang sejak tanggal 18 Agustus 1945 telah ditetapkan sebagai pondasi NKRI dan menurut memorandum DPR-GR tanggal 9 Juni 1966 yang kemudian ditetapkan oleh majelis permusyawaratan rakyat sementara dengan eketatapan MPRS No. XX/MPRS/1966 yang isinya antara lain menyebutkan bahwa pancasila adalah pandangan hidup bangsa (masyarakat) Indonesia yang telah di murnikan dan diapadatkan menjadi dasar negara republik Indonesia (Sunarso, Lasiyo, Eknathon, 2002).

Pancasila sebagai Jiwa Bangsa Indonesia, Jiwa Pancasila adalah jiwa (soul) masyarakat Indonesia memiliki sifat statis (tetap, tidak boleh diganti dan diubah) dan juga memiliki sifat dinamis sebagai penggerak sehingga menimbulkan keinginan cita-cita luhur bangsa Indonesia, yang dijiwai Pancasila, oleh bangsa Indonesia diperjuangkan untuk menjadi suatu kenyataan. Dengan demikian bangsa Indonesia bertekad untuk melaksanakan tujuan yang sudah termaktub dalam pembukaan UUD 1945.

Pancasila sebagai Kepribadian Bangsa, Yang dimaksud dengan kepribadian (personality) yaitu sikap mental amal perbuatan dan tingkah laku. Pancasila sebagai kepribadian bangsa berarti bahwa pancasila itu merupakan ciri khas bangsa Indonesia yang tercermin dalam sikap mental, amal perbuatan dan tingkah laku sehari-hari warga negara indonesia sehingga dapat membedakan masyarakat Indonesia dengan bangsa yang lain.

Pancasila sebagai sumber dari segala sumber hukum maupun sumber tertib hukum bangsa Indonesia. Ketetapan MPRS No. XX/MPRS/1966 yang kemudian ditegaskan pada ketetapan MPRS No. V/MPRS/1973 dan ketetapan MPR No. IX/MPRS/1978 yang menerima baik isi memorandum DPR-GR tanggal 9 Juni 1966 yang berisi tentang tertib hukum Indonesia dan tata urutan peraturan perundangan Republik Indonesia (Sunarso, Lasiyo, Eknathon, 2002).

Pancasila sebagai perjanjian luhur bangsa Indonesia, ditetapkan pancasila sebagai dasar (NKRI) negara republik Indonesia pada tanggal 18 Agustus 1945 oleh PPKI. Dapat disimpulkan bahwa pancasila merupakan perjanijian luhur dari seluruh bangsa Indonesia.

Cita-cita dan tujuan bangsa Indonesia, Penuangan jiwa proklamasi 1945 itu merupakan jiwa pancasila, tujuan negara Indonesia, yaitu tujuan nasional: 1) Melindungi bangsa Indonesia dan seluruh tumpah darah Indonesia, 2) Memajukan kesejahteraan umum, dan 3) Mencerdaskan kehidupan bangsa. Tujuan internasional, yaitu ikut melaksanakan ketertiban dunia yang berdasarkan perdamaian abadi dan keadilan sosial.

Pancasila sebagai pemersatu, Sebagai alat pemersatu karena materi dari pancasila itu diambil dari puncak-puncak kebudayaan, agama, dan kepercayaan dan adat-istiadat yang ada di seluruh wilayah Indonesia. Pancasila sebagai Filsafat bangsa Indonesia, dalam arti pancasila sebagai dasar berpijak setiap warga negara Indonesia dalam segala aktivitasnya. Dan pancasila merupakan tolak ukur bagi tindakan manusia Indonesia. Pancasila sebagai ideologi Negara, merupakan dasar yang paling fundamental daripada negara republik Indonesia, atau merupakan pokok inti kaidah negara fundamental. Pancasila sebagai Ideologi negara, didalamnya ada tiga (3) faktor yang cukup jelas yaitu, adanya keyakinan (believe) dan cita-citakan (tujuan), serta cara yang musti dijalani untuk tercapainya tujuan hidup (cita-cita), maka secara eksplisit telah memenuhi ketiga faktor tersebut (Sunarso, Lasiyo, Eknathon, 2002).

Pancasila merupakan roh kebangsaan yang bersifat inklusif, merangkul semua golongan sosial, etnis, agama, bahasa, dan aspirasi hidup. Nilai paling dasar pancasila adalah keluhuran martabat manusia. Hal ini dilatarbelakangi pengalaman masa penjajahan, diskriminasi yang masih kuat, segregasi sosial, dan ketidakadilan ekonomi yang dapat bermuara pada perpecahan bangsa. Pancasila sebagai falsafah bangsa sangat mengayomi kebhinekaan Indonesia sehingga 
memberika ruang yang sama kepada semua kelompok untuk memaknai dan mengimplementasikan nilai-nilai Pancasila sesuai nurani keberadaannya.

Pernyataan Soekarno secara jelas mengisyaratkan bahwa Negara Pancasila bukanlah monopoli sekelompok agama karena prinsip keadilan dan kemajemukan merupakan identitas bangsa. Kesadaran inilah yang mendorong mantan menteri agama Munawir Syadzali berani mendeklarasikan bahwa model negara modern yang dianut Indonesia adalah model terbaik yang perna dipikirkan sehingga harus menjadi tujuan akhir bagi muslim Indonesia.

Dalam menanggapi reaksi umat islam terhadap pancasila, suharto mengeluarkan tiga pernyataan: 1) Pancasila tidak akan dijadikan agama dan agama tidak akan disamakan dengan pancasila, 2) Pancasila bukanlah alternatif, saingan atau pengganti agama, dan 3) Pancasila tidak akan menagtur atau mencampuri keimanan dan ajaran agama (Ruslan, 2015). Penerimaan NU terhadap pancasila, juga mempunya keterkaitan dengan aspek historis, yaitu K.H. wahid Hasyim seorang tokoh NU yang terlibat langsung dalam perumusan pancasila dan UUD 1945 bersamasama dengan pemimpin Nasional-Muslim lain.

\section{Filsafat Pancasila}

Filsafat pancasila dapat didkonsepsikan sebagai refleksi yang kritis sesuai logika dan rasional (berdasarkan akal) tentang pancasila sebagai dasar (fondasi) negara dan kenyataan budaya (adat) bangsa, dengan tujuan untuk menemukan pokok-pokok (nilai) pengertiannya yang mendalam dan menyeluruh (Hadi, 2019). Pancasila dinyatakan sebagai filsafat karena pencasila merupakan hasil penghayatan jiwa yang mendalam yang dilakukan oleh founding father Indonesia, yang dituangkan dalam suatu sistem. Pengertian filsafat pancasila secara umum adalah hasil berfikir (think) atau pemikiran yang sedalam-dalamnya (sampai ke akar) dari bangsa (masyarakat) Indonesia yang dipercaya, dianggap, dan diyakini sebagai kenyataan (realis), norma-norma (hukum) dan nilai-nilai yang benar, bijaksana, adil, dan paling sesuai dengan kehidupan dan kepribadian bangsa Indonesia.

Filsafat pancasila kemudian ditumbuh kembangkan oleh Soekarno sejak 1955 sampai pemerintahannya berakhir 1965. Pada saat itu Soekarnomenyatakan bahwa Pancasila merupakan bagian filsafat asli Indonesia yang ditemukan dari budaya, adat dan tradisi (nilai luhur) Indonesia serta merupakan akulturasi (pencampuran) Barat (Kristen), budaya India (Hindu-Budha), dan Arab (Islam) (Widodo, Wahyu, 2015). Filsafat Pancasila menurut soeharto telah mengalami Indonesianisasi. Semua sila (dasar) dalam Pancasila adalah asli diambil dari budaya Indonesia dan selanjutnya ditafsirkan menjadi lebih rinci ke dalam butir-butir pancasila.

Filsafat pancasila ini digolongkan sebagai filsafat praktis (realis) sehingga Pancasila tidak hanya mengandung pemikiran dan perasaan yang sedalam-dalamnya atau tidak hanya bertujuan mencari (seeking), tetapi hasil pemikiran yang berwujud filsafat Pancasila tersebut dipergunakan sebagai petunjuk hidup sehari-hari agar hidup bangsa Indonesia dapat mencapai kebahagiaan lahir dan batin, baik di dunia maupun diakhirat. Sebagai filsafat, pancasila memiliki dasar mendalam terkait ontologis, epistimologis, dan aksiologis (Maftuh, 2008).

Dasar ontologis Pancasila membuktikan bahwa jelas bahwa Pancasila itu sungguh ada dalam realitas dan entitas bangsa (rakyat) Indonesia yang berdasar atas multikulturalisme. Dasar epistimologinya, yakni berisi suatu cara, metode, strategi, norma, agar sesuatu yang lain dapat kembali kepada sebabnya. Sila ketiga persatuan dan sila keempat yang memiliki subtansi asas demokrasi, merupakan landasan epistimologi bangsa Indonesia (Sunarso, Lasiyo, Eknathon, 2002). Secara aksilogis, pancasila memiliki 5 sila yang saling berkaitan dan bermakna yang membentuk manfaat bagi masyarakat indonesia. Dan dari nilai-nilai Pancasila mulai dari ketuhanan, kemanusiaa, persatuan, karakyatan, dan keadilan sosial digunakan untuk mencapai cita-cita bangsa Indonesia salah satunya melalui Pendidikan (Muslimin, 2016).

Dalam hal ini, menurut pandangan pemateri mengambil pendapat Notonagoro nilai-nilai abstrak yang bermuara dari hakikat (sebenanya) Tuhan, manusia, satu, rakyat dan adil, dijabarkan menjadi konsep dalam etika Pancasila, bahwa inti manusia (masyarakat) Indonesia adalah untuk memiliki sikap dan situasi yang berketuhanan, berkemanusiaan, berkebangsaan, berperi kerakyatan dan berperi keaadilan sosial. Konsep Pancasila yang berasaskan tematis dijabarkan menjadi sistem Etika Pancasila yang bercorak normative (Notonagoro, 1972). Isi 
Pancasila yang disebut abstrak universal sebagai prinsip dasar/fondasi dapat menjadi sumber dan landasan bagi penyelesaian masalah, baik masalah dalam kehidupan personal sehari-hari.

\section{Kesadaran Masyarakat Muslim Yang Berlandaskan Falsafah Bangsa Pancasila}

Dasar negara Indonesia adalah Pancasila dan UUD 1945, dengan demikian keduanya harus menjadi pedoman bagi masyarakatnya (termasuk yang muslim) sila-sila dari pancasila, bagi Notanegoro memuat filosofi bangsa Indonesia yang satu sama lain tersampul (adanya persatuan dan kesatuan). Untuk masing-masingnya harus dipahami melalui Nilai-nilai fundamental dalam pancasila (Rosadi, 2010). Apabila masyarakat yang akan diwujudkan oleh bangsa secara bersama ialah masyarakat adil makmur berdasarkan Pancasila dan UUD 1945 yang singkatnya dapat disebut dengan Masyarakat Pancasila, maka dalam kondisi demikian sudah barang tentu agama harus secara fungsional terletak dalam mekanisme dan dinamika bangsa dan negara (Wijaya, 2008).

Kesadaran memiliki makna pemahaman seseorang terhadap realitas/fenomena yang didalamnya terjadi proses konstitusi (pengemasan) terhadap fenomena itu, sehingga ia dipahami sedemikian rupa sampai kepada halnya (das ding an sich) secara objektif (Usman, 2013). Merujuk kepada kesadaran masyarakat muslim yang hakekatnya, ada 4 yakni nalar jahiliyah, nalar deduktif (diniyyah), nalar induktif (ilmiyyah), dan bernalar abduktif (hanifiyyah). Hanifiyyah menggambarkan bahwa penanganan kehidupan bedasar pada nalar abduktif adalah lebih menjamin kepada ketercapaian kepentingan hidup yang sangat human (Nugroho, 2017). Pluralitas umat manusia merupakan kenyataan yang dikehendaki Allah SWT yang tak dapat dielakan lagi, firman-Nya: "Hai manusia, sesungguhnya Kami (Allah) telah menciptakan kamu dari seorang laki-laki dan seorang perempuan dan menjadikan kamu berbangsa-bangsa dan bersuku-suku supaya kamu saling mengenal. Sesungguhnya orang yang paling mulia di antara kamu di sisi Maha Mengenal" (QS al-Hujurat/49:13). "Dan di antara tanda-tanda kekuasaan-Nya ialah menciptakan langit dan bumi serta berlain-lain bahasamu dan warna kulitmu. Sesungguhnya pada yang demikian benar-benar terdapat tanda-tanda bagi orang-orang yang mengethui" (QS al-Rum/30:22) (Abidin, 2014). Kelompok masyarakat Indonesia merupakan masyarakat dengan tingkat keanekaragaman serta perbedaan yang sangat kompleks atau majemuk. Kelompok masyarakat dengan bebagai keanekaragaman dan kemajemukan tersebut dikenal dengan istilah masyarakat multikultural atau Multicultural society (Kariyadi \& Suprapto, 2017).

Berdasar itu tentunya dapat dilakukan analisa lebih mendalam tentang pentingnya perubahan nalar masyarakat muslim Indonesia secara lebih umum. Artinya perlu ditemukan upaya strategis untuk merubah nalar masyarakat muslim secara umum menuju kepada yang lebih fungsional, tepat guna dan berdaya guna seperti yang dimiliki oleh mereka yang abduktif (Shofa, 2016). Hal pokok yang diharapkan, pertama, karakter masyarakat Indonesia (termasuk muslim) yang diharapkan oleh pemerintah. Kedua, sumbangsih (suatu strategi kebudayaan) dalam pengelolaan dan pengembangan jenis kesadaran masyarakat muslim Indonesia dari yang jahiliyah, diniyyah, serta ilmiyyah, manuju kepada yang hanafiyyah, yang dipandang lebih human. Adapun Strategi Membentuk Manusia Berkarakter.

Dalam hal ini, penulis memilki pendapat bahwa realisasi implementasi Pancasila dalam berkehidupan dalam hal pengkhususan, dari formatnya yang abstrak menjadi pengertian yang umum kolektif (terkumpul) dan khusus (konkret). Bangsa Indonesia dengan Falsafah Pancasila mempunya hubungan yang berasaskan kausalitas, mengandung unsur kewajiban. Pancasila sebagai sebab dan adanya bangsa Indonesia sebagai akibatnya.

Dalam pembentukan karakter menuju terbentuknya akhlak yang mulia dalam diri setiap peserta didik ada tiga tahapan yang harus dilalui, diantaranya (Majid, 2012): Moral Knowing/Learning to, moral loving/moral feeling, dan moral doing/learning to do. Namun disempurnakan dalam buku filsafat pendidikan islam dalam pembentukan karakter. Jika karakteristik merupakan 100\% keturunan sejak lahir, maka karakter tidak dapat dibuat (diciptakan). Namun, jika heriditas hanyalah bagian dari berbagai bagian pembentuk karakter, tentu saja jawabannya dapat dibuat mulai usia dini menuju dewasa. Corak pendidikan karakter holistik (formal, informal dan nonformal) memiliki tujuh rukun. Ketujuh rukun pendidikan yang 
bercorak karakter berikut adalah sebuah bentuk yang utuh dan meyeluruh yang dapat diarahkan secara berurutan dan tidak berurutan. Suatu perilaku barulah bisa menghasilkan manusia berkarakter, apabila tsemua rukun pendidikan karakter berikut ini dikerjakan secara menyeluruh. Kelima rukun itu adalah sebagai berikut (Siregar, 2018), yakni, Rukun Pertama: Moral Acting (tindakan yang baik) dengan cara habituasi (pembiasaan) dan pembudayaan, Rukun Kedua: Membelajarkan pengetahuan tentang nilai-nilai yang baik (moral knowing), Rukun Ketiga: Moral feeling dan loving: merasakan dan mencintai yang baik, Rukun Keempat: Keteladanan (moral model) dari lingkungan sekitar, dan Rukun Kelima: Pertaubatan dari segala dosa dan hal-hal yang tidak bermanfaat sekalipun boleh (tidak berdosa) dengan melaksanakan takhalli, tahalli, dan tajalli

Dalam konteks ini masdar farid mengemukakan, pada alenia keempat pembukaan UUD 1945 mengandung perihal lima prinsip dasar bagi kehidupan bermasyarakat, berbangsa dan bernegara yang hendak dibangun dan dicapai, lima prinsip dasar itulah yang disebut pancasila (Yusuf, 2013). Berikut nilai-nilai fundamental dalam pancasila:

Sila Pertama yaitu ke-tuhanan yang maha esa, selain menjiwai sila-sila yang lainnya dari pancasila, menurut hardono Hadi perlu dinyatakan dengan tegas bahwa Indonesia menemukan prinsip dasar yang mempersatukan segalanya, tersebut di dalam "ke-tuhanan Yang Maha Esa" sebagaimana dirumuskan dalam sila pertama dari pncasila. Sila pertama ini merupakan sikap yang paling mendalam dari bangsa Indonesia (Yusuf, 2013). Artinya dalam sila pertama itu terkandung selain nilai ke-tuhanan dan religius, juga terdapat nilai kesatuan dan persatuan, dimana nilai-nilai tersebut mengikat manusia dalam satu keyakinan terhadap Tuhan yang Maha Esa dana Maha Pencipta. Hal tersebut reflektif merupakan cerminan atau implementasi dari paham ontologis monodualisme (manusia dan tuhan tidak terpisahka), yang sebenarnya telah diyakini oleh rakyat Indonesia. dengan kata lain bahwa ke-Tuhanan yang maha esa rakyat Indonesia menyatakan kepercayaan dan ketaqwaan terhadap Tuhan yang Maha Esa (Yusuf, 2013).

Sila kedua: kemanusiaan yang adil dan beradab soejadi menegaskan kandungan nilai kemanusiaan tersebut meliputi: a) Pengakuan terhadap harkat dan martabat dngan segala hak dan kewajiban asasinya, b) Perlakuan dan pekerjaan yang adil antar sesama manusia, lingkungan sekitar, dan seluruh komponennya, c) Manusia sebagai makhluk yang memilki adab yang memiliki daya cipta, rasa dan keyakinan.

Sila ketiga: persatuan Indonesia, dalam pandangan Kohdi dan Soejahdi, nilai tersebut mengandung nilai sebagai berikut: a) Pengakuan terhadap kebhineka tunggal ika suku bangsa (etnis), agama, adat-istiadat dan kebudayaan, b) Pengakuan terhadap persatuan bangsa dan wilayah NKRI serta wajib membela dan mempertahankan serta wajib menjunjung tinggi (patriotisme), c) Memilki rasa cinta dan bangga akan bangsa dan negara Indonesia. secara reflektif pengakuan terhadap keragaman etnis, adat, kebudayaan, agama dan sebagainya itulah hakikat sejatinya persatuan Indonesia.

Sila keempat: kerakyatan yang dipimpin oleh hikmat kebijaksanaan dalam permusyawaratan/perwakilan. Nilai kerakyatan tersifat pada negara Indonesia adalah dari rakyat, oleh rakyat dan untuk rakyat. Dalam pengertian ini, semua kebijakan dan keputusan penguasa atau pemerintahan negara harus sejalan dengan keinginan dan berpihak pada kepentingan rakyat. Selain itu, kebijakan dan berbagai keputusan harus dilahirkan melalui musyawarah dan mufakat bersama wakil-wakil rakyat.

Sila kelima: Keadilan sosial bagi seluruh rakyat Indonesia. menurut Notonegoro secara filosofis menunjukkan bahwa didalam sila-sila pancasila terdapat nilai-nilai fundamental, antara lain adalah nilai ke-Tuhanan, peri kemanusiaan, peri persatuan, nilai peri kerakyatan atau kebersamaan, dan nilai keadilan, dan nilai-nilai ini benar-benar ada pada rakyat Indonesia.

Kamudian bagaimana implementasi konkrit dari falsafah Pancasila dan amanat UUD 1945 tersebut oleh masyarakat muslim Indonesia dalam bentuk perilaku? Hal itu dapat ditemukan pada konsep pembinaan karakter bangsa Indonesia sebagaimana yang ditetapkan oleh pemerintah melalui kementerian pendidikan Nasional. Pemerintah menegaskan hal itu secara implisit dalam Rencana Pembangunan Jangka Panjang (RPJPN) tahun 2005-2025. Didalamnya dinyatakan bahwa pembangunan karakter merupakan salah satu program prioritas 
pembangunan nasional untuk mencapai tujuan dan ditetaokanlah UU No.20 tahun 2003 tentang sistem pendidikan nasional (Sutono, 2015).

Guna mencapai itu maka dirumuskanlah sembilan karakter yang khas bangsa Indonesia, yaitu tangguh, kompetitif, berakhlak, berakhlak mulia, bermoral, bertoleran, bergotong-royong, berjiwa patriotik, dijiwai oleh IMTAQ kepada Tuhan yang Maha Esa berdasarkan Pancasila. Kemudian secara epistimologis, dengan berdasar pada analisis, maka dapat dimaknai bahwa masyarakat Indonesia yang Pancasilais termasuk muslim, memahami suatu realitas/kebudayaan sudah semestinya dalam pengertian yang utuh yakni empirik-rasional-intuitif, sebagaimana yang dimaksudkan dalam sila-sila Pancasila serta UUD 1945 secara terpadu utuh/satu, lahir batin, individual-sosial, makhluk-pribadi-makhluk Tuhan. Artinya memahami realitas secara utuh, empirik-rasional-intuitif diakui adanya yang sekaligus memberi inspirasi pada pengetahuan/pemahamannya dan harus terimplementasikan dalam kenyataan hidupnya.

\section{Simpulan dan saran}

Masyarakat muslim yang berlandaskan falsafah bangsa (pancasila) mamahami bahwa epistimologi pendidikan dan cara memperoleh pendidikan itu sebagai landasan untuk membentuk negara dan bangsa yang memiliki keyakinan, kemanusiaan, persatuan, permusyawaratan dan keadilan yang dibangun dalam lembaga pendidikan yang sama sekali tidak bertentangan dengan rasional, empiris dan normatif khususnya bagi masyarakat muslim. Pancasila adalah rumah bersama, tempat semua kelompok agama (termasuk islam) dapat mengisi dan memperkaya nilai-nilai luhur kemanusiaan yang menjadi inti Pancasila. Landasan berpikir masyarakat muslim yang berlandaskan pancasila ialah rasional, empirik dan intuitif. Menjadi masyarakat yang hanafiyyah, menjadikan nalar abduktif sebagai jalan untuk menjadikan bangsa Indonesia yang memiliki rasa keyakinan, rasa kemanusiaan, rasa persatuan, rasa musyawarah, dan rasa keadilan yang diwujudkan dalam kehidupan sehari-hari. Indonesia yang berlandaskan Pancasila menolak keras berbagai paham yang melawan atau yang tidak sesuai dengan nilai-nilai Pancasila sebagai asas negara Indonesia contohnya khilafah Islamiyah. Peneliti merekomendasikan untuk melakukan penelitian lebih lanjut, dengan menggunakan paradigma dan metodologi yang berbeda, dan mengurai lebih dalam satu persatu tentang klasifikasi yang dijelaskan diatas lebih rinci dan lebih mendalam.

\section{Daftar Rujukan}

Abidin. (2014). Teologi Inklusif Nurcholish Madjid: Harmonisasi Antara Keislaman, Keindonesiaan, Dan Kemoderenan. Humaniora, 5(2).

Adi, P. (2016). Pembudayaan Nilai-Nilai Pancasila Bagi Masyarakat Sebagai Modal Dasar Pertahanan Nasional Nkri. Jurnal Moral Kemasyarakatan, 1(1), 15-36.

Asmaroini, A. P. (2017). Menjaga Eksistensi Pancasila Dan Penerapannya Bagi Masyarakat Di Era Globalisasi. JPK: Jurnal Pancasila Dan Kewarganegaraan, 1(2), 12-21.

Hadi, A. (2019). Moralitas Pancasila Dalam Konteks Masyarakat Global: Mengkaji Pendidikan Kewarga Negaraan Untuk Penguatan Nilai Moral Dalam Konteks Globalisasi. Jurnal Intelektualita: Keislaman, Sosial, Dan Sains, 8(2).

Kariyadi, D., \& Suprapto, W. (2017). Membangun Kepemimpinan Berbasis Nilai-Nilai Pancasila Dalam Perspektif Masyarakat Multikultural. Citizenship Jurnal Pancasila Dan Kewarganegaraan, 5(2), 86. Https://Doi.Org/10.25273/Citizenship.V5i2.1560

Maftuh, B. (2008). Internalisasi Nilai-Nilai Pancasila Dan Nasionalisme Melalui Pendidikan Kewarganegaraan. EDUCATIONIST, II(2).

Majid, A. \& Andriani. (2012). Pendidikan Karakter Perspektif Islam. Bandung: PT. Remaja Rosdakarya.

Muslimin, H. (2016). Tantangan Terhadap Pancasila Sebagai Ideologi Dan Dasar Negara Pasca Reformasi. Jurnal Cakrawala Hukum, 7(1), 30-38. Https://Doi.Org/10.26905/Idjch.V7i1.1791

Notonagoro. (1972). Generasi Muda Dan Ketuhanan Nasional. Yogyakarta: Sema Universitas Gadjah Mada.

Nugroho, D. A. (2017). Penguatan Ecological Citizenship Melalui Penerapan Pendidikan 
Pancasila Dan Kewarganegaraan Berbasis Masyarakat. Prosiding Konferensi Nasional Kewarganegaraan III, (November), 18-25.

Qomar, M. (2005). Epistemologi Pendidikan Islam. Jakarta: Erlangga.

Rosadi, O. (2010). Hukum Kodrat, Pancasila Dan Asas Hukum Dalam Pembentukan Hukum Di Indonesia. Jurnal Dinamika Hukum, 10(3), 282-290. Https://Doi.Org/10.20884/1.Jdh.2010.10.3.98

Ruslan, I. (2015). Negara Madani Aktualisasi Nilai-Nilai Pancasila Dalam Kehidupan Berbangsa Dan Bernegara. Yogyakarta: SUKA Press.

Shofa, A. M. A. (2016). Memaknai Kembali Multikulturalisme Indonesia Dalam Bingkai Pancasila. JPK Uurnal Pancasila Dan Kewarganegaraan), 1(1), 34-41. Https://Doi.Org/10.24269/V1.N1.2016.34-40

Siregar, M. (2018). Pendidikan Islam Menuju Pembentukan Karakter. Yogyakarta: FITK UIN Sunan Kalijaga.

Sunarso, Lasiyo, Eknathon, Dan R. (2002). Pancasila. Yogyakarta: PPKP Press.

Suparno, P. (2001). Filsafat Pendidikan. Yogyakarta: Penerbit Kanisius.

Sutono, A. (2015). Meneguhkan Pancasila Sebagai Filsafat Pendidikan Nasional. Civis, 5(1), 666678. Retrieved From Http://Journal.Upgris.Ac.Id/Index.Php/Civis/Article/View/628

Usman. (2013). Jenis Kesadaran/Paradigma Masyarakat Muslim. Yogyakarta: Pustaka Pelajar.

Wahid, A. A. (2013). Diskursus Pendidikan Berbasis Karakter. Jakarta: Risalah.

Widodo, Wahyu, B. A. (2015). Pendidikan Pancasila Hakikat, Penghayatan Dan Nilai-Nilai Dalam Pancasila. Yogyakarta: Pustaka Andi.

Wijaya, A. (2008). Kedudukan Norma Hukum Dan Agama Dalam Suatu Tata Masyarakat Pancasila. Al-Qānūn, 11(2).

Yusuf, H. (2013). Dasar-Dasar Aksiologis Pembukaan UUD 1945 Dalam Perspektif Filsafat Politik Islam. Bandar Lampung: An-Nuur Press. 